\title{
Ethnobotany and Ethnomedicinal Uses, Chromosomal Status and Natural Propagation of Some Plants of Lahaul-Spiti and Adjoining Hills
}

\author{
Puneet Kumar and Vijay Kumar Singhal \\ Department of Botany, Punjabi University, Patiala, Punjab 147 002, India \\ Correspondence should be addressed to Puneet Kumar; puneetbotcyto@gmail.com
}

Received 18 July 2013; Accepted 22 September 2013

Academic Editor: Philip J. White

Copyright (C) 2013 P. Kumar and V. K. Singhal. This is an open access article distributed under the Creative Commons Attribution License, which permits unrestricted use, distribution, and reproduction in any medium, provided the original work is properly cited.

\begin{abstract}
The present study documented the ethnobotanical and medicinal uses of plants from an ecologically fragile cold desert area of Lahaul-Spiti (Himachal Pradesh, India). Local people use plants for curing the stomach troubles, pain reliever, cough, gastric disorders, and aphrodisiac and other household purposes. In addition, chromosome numbers, male meiosis, and natural propagation were also investigated in these ethnobotanically used plants. Present investigations also form the basis for exploitation of intraspecific chromosomal variation/new cytotypes recorded in some of the presently studied species to detect biochemical diversity in the medicinally important plants. For documentation of ethnobotanical information, personal observations and interviews were conducted with medicine men, hakims, farmers, shepherds, local healers, and old aged people. This study identified 40 plant species under 33 genera belonging to 17 families which have been used locally for curing various diseases and other purposes. All the chromosome counts are new to the study area. On worldwide basis, meiotic chromosome counts of $n=14$ and $n=8$ in Rosularia alpestris and Corydalis govaniana, respectively, are the first ever reports. The present study indicates that the people of the area possess good knowledge about the different uses of plants in the area. It has been noticed that due to the lack of interest among younger generations in the preservation of invaluable ethnic knowledge, there is every possible chance of losing such a rich heritage of knowledge. It is very urgent to conserve such invaluable ethnic knowledge before it gets lost.
\end{abstract}

\section{Introduction}

Present study was conducted in Lahaul-Spiti, a cold and desolate alpine region in northwest Himalayas which is known for its seclusion, Buddhist culture, hostile climate, and unexplored, formidable, and breathtaking scenic beauty of the high snow clad mountains. It is a part of the Indian cold deserts which is situated between $31^{\circ} 44^{\prime} 57^{\prime \prime}$ and $32^{\circ} 59^{\prime} 57^{\prime \prime} \mathrm{N}$ latitudes and between $76^{\circ} 29^{\prime} 46^{\prime \prime}$ and $78^{\circ} 41^{\prime} 34^{\prime \prime} \mathrm{E}$ longitudes. Climatic conditions are typical of dry temperate and alpine zones. The vegetation which is mainly composed of perennial herbs and prostrate shrubs survives extreme variation in temperature including months buried under several feet of snow. Using plants for different purposes and in curing and healing is as old as man himself [1]. It was very well known to primitive people that plants contain beneficial and medicinal properties which they used in some form or the other. Even in the ancient time, people classified plants on the basis of their medicinal uses. No comprehensive attempt has been made so far to gather ethnobotanical information and to assess the cytological diversity and natural propagation of the plants growing in the higher altitude and cold desert regions of Lahaul-Spiti. Presently an attempt has been made to collect information on the ethnobotanical uses and to examine the cytomorphological diversity and natural propagation in the species of Lahaul-Spiti and adjoining high hills.

1.1. Topography and Vegetation. The topography of the area is entirely different from the adjoining regions of northwest Indian Himalayas. The cold desert plants of Lahaul-Spiti show a wide range of habitat diversity which includes alpine pastures and slopes, moist shady and exposed places, forests and forest undergrowth, water courses, scree slopes, rock crevices, rocks/boulders, roadsides, riverbeds, and sandy 


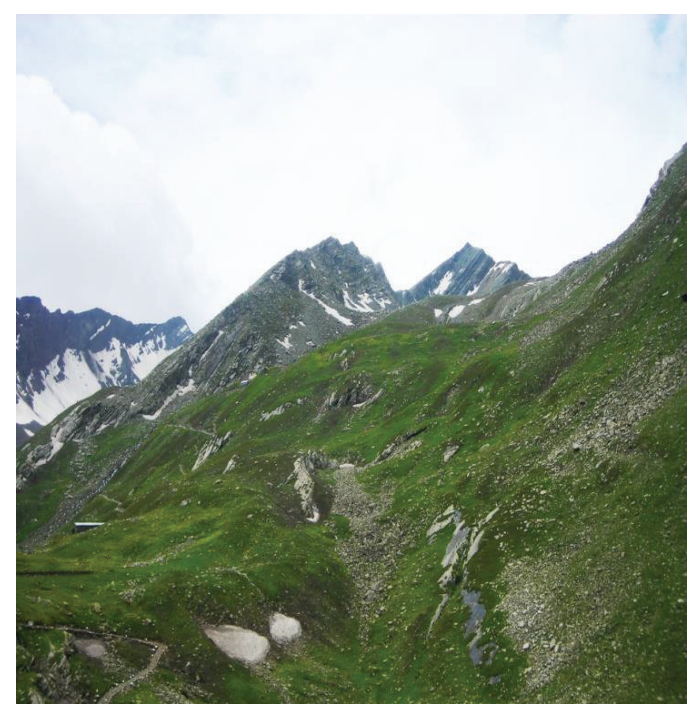

(a)

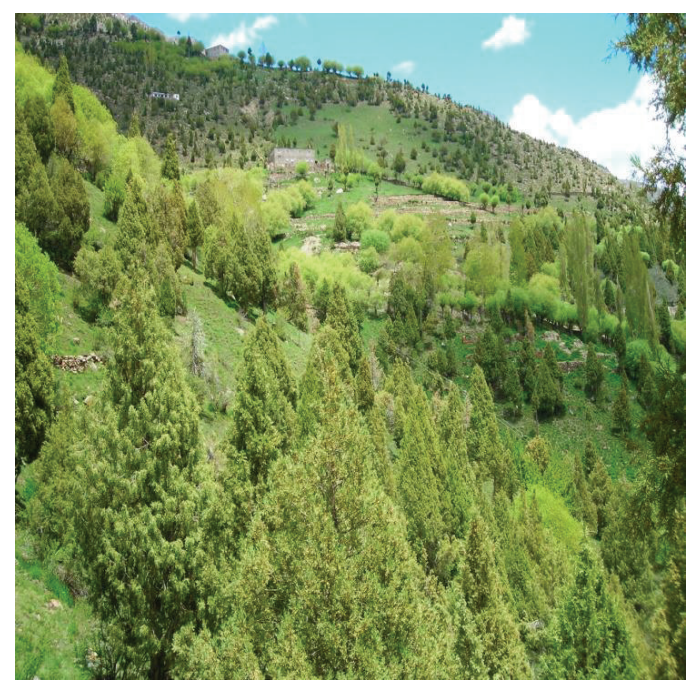

(c)

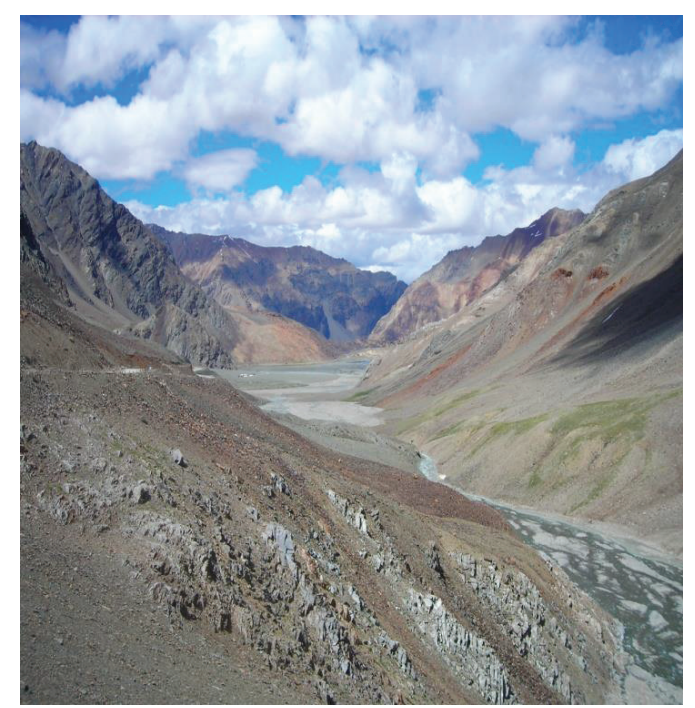

(b)

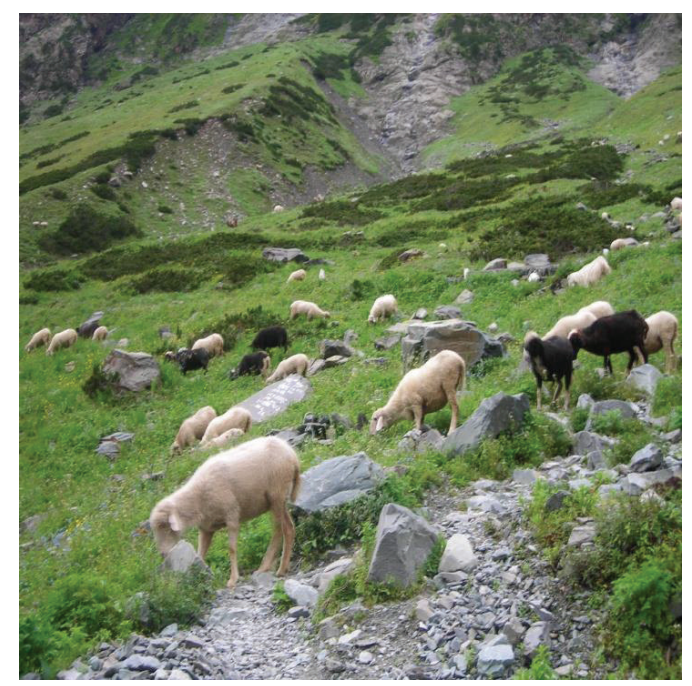

(d)

Figure 1: (a) Alpine pasture. (b) A part of Lahaul Valley near Baralacha Pass with scanty vegetation. (c) Dry temperate forests near Keylong. (d) Sheep grazing on alpine moist slopes.

areas (Figures 1(a)-1(d)). The Lahaul-Spiti which is the largest district of Himachal Pradesh with an area of ca. $13835 \mathrm{~km}^{2}$ consists of two regions (Lahaul Valley and Spiti Valley) which are different in many aspects. One such aspect is the vegetation which is quite different. The Lahaul Valley is on the greener side compared to the barren Spiti region where climate is much drier. Since the district possesses a great range of elevation, ranging from 2400 to $6500 \mathrm{~m}$, the vegetation is diverse, unique, and plentiful. It comprises dry temperate to high alpine type except for some parts of Pattan Valley (Lahaul) adjoining the Pangi area of Chamba district, where it is of dry temperate to moist temperate type (Figure 1(c)).

\section{Materials and Methods}

2.1. Information Collection, Fixation of Material for Cytological Studies, Identification of Plants, and Male Meiotic Chromosome Counts. As the valley remains cut off from other parts of country for more than six months due to heavy snow fall, observations on ethnobotanical information and natural propagation and collection of material for cytological studies were made between June and October in the years 2006-2009. During the intensive cytomorphological and ethnobotanical surveys, 40 plant species used by the local people of Lahaul-Spiti had been collected from different localities (Figure 2). For documentation of ethnobotanical information, personal observations and interviews were conducted with medicine men, hakims, farmers, shepherds, local healers, and old aged people. Plant identification was done by consulting the Flora of Lahaul-Spiti [2], the Flora of Kullu district [3], and Flora of Chamba district [4]. Besides, the plant accessions were also compared to the samples lying in the Herbaria of the Department of Botany, Punjabi University, Patiala (PUN), Botanical Survey of India (BSI), and Forest Research Institute (FRI) at Dehra Dun. Voucher 


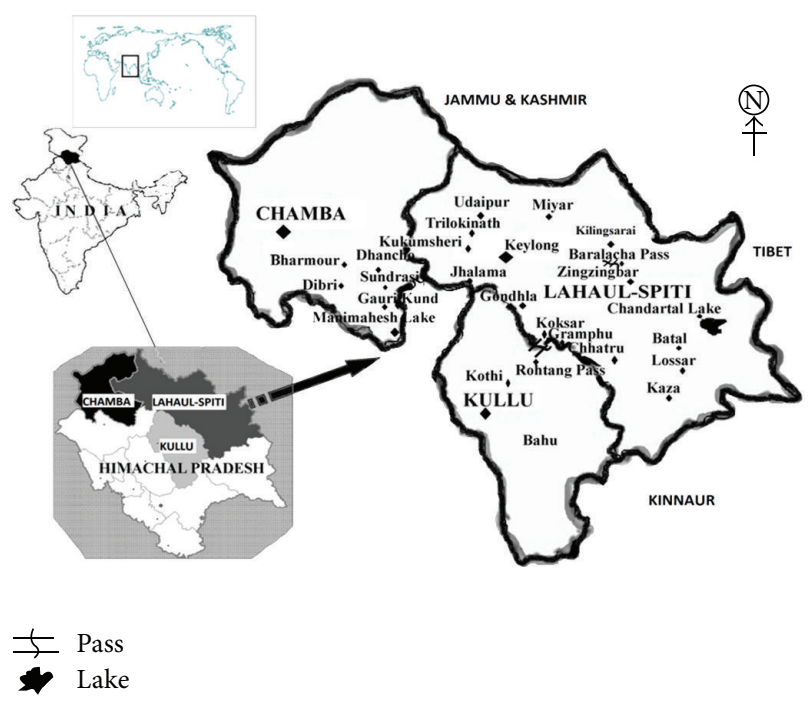

Figure 2: Study area: Lahaul Spiti, Chamba, and Kullu districts of Himachal Pradesh (India).

specimens of the cytologically worked-out specimens were deposited in the Herbarium, Department of Botany, Punjabi University, Patiala (PUN). For male meiotic studies, floral buds of suitable sizes from the wild plants were fixed in Carnoy's fixative (mixture of ethanol, chloroform, and glacial acetic acid in volume ratio of $6: 3: 1)$ for $24 \mathrm{~h}$ and preserved in $70 \%$ ethanol in a refrigerator until analysed. For chromosome counts and detailed meiotic behavior in pollen mother cells (PMCs) at early prophase-I, metaphase-I (MI), anaphase-I/II (AI/II), telophases-I/II (TI/II), and sporad stage developing anthers were squashed in $1 \%$ acetocarmine. Pollen fertility was estimated through stainability tests by smearing mature anthers from different flowers in glycerol-acetocarmine mixture $(1: 1)$ and aniline blue dye (1\%). Best plates of chromosome counts, meiotic abnormalities, sporads, and pollen grains were photographed from the temporary mounts with digital imaging system of Nikon Eclipse $80 i$ microscope and Leica QWin. Field photographs of plants and landscape were taken with Nikon Coolpix L3 camera.

\section{Results}

3.1. Ethnobotany. In the present investigation, 40 plant species under 33 genera belonging to 17 families have been reported to be used for ethnobotanical and medicinal purposes. Data given in Table 1 includes the name of the family to which a particular species belongs, their meiotic chromosome number, ploidy level, vernacular name, locality and its altitude, voucher specimen number, habit and habitat, natural regeneration, flowering and fruiting period, plant part used, and ethnobotanical uses (Figures 3(a)-3(g)). Out of the 40 species, the maximum number of species belongs to Ranunculaceae and Leguminosae with 7 species each and 4 species to Apiaceae and Rosaceae each. The most common plant parts used in different preparations are the roots and leaves. Other plant parts used as herbal medicine are whole plant, seeds, fruits, flowers, and rhizomes. Based on the information gathered from different sources, the local people used a good number of plant species for curing the stomach troubles, pain reliever, cough, gastric disorders, and aphrodisiac; as fodder and fuel; to obtain different dyes; and in religious ceremonies and as offerings to deities (Figures 4(a)-4(d)).

3.2. Chromosomal Status. In addition to the gathering of ethnobotanical information, chromosome number and details of male meiosis have also been investigated in all the species. Of the 40 cytologically studied species, 30 (75\%) exist at diploid level with basic chromosome number ranging between $\mathrm{x}=$ 5 (Biebersteinia odora Steph. ex Fish., $2 n=10$ ) and 18 (Cerastium cerastoides (L.) Britt., $2 n=36$ ), while nine (22.5\%) of them were found to be at polyploid level $(4 \mathrm{x}, 6 \mathrm{x}, 12 \mathrm{x})$. One species, Ranunculus hirtellus Royle $(2 n=16,32)$, existed at both diploid and tetraploid levels based on $\mathrm{x}=8$. All the chromosome counts are new to the study area. On worldwide basis, meiotic chromosome counts of $n=14$ (Figure 5(a)) and $n=8$ (Figure 5(b)) in Rosularia alpestris (Kar and Kir) Boriss. and Corydalis govaniana Wall., respectively, are the first ever chromosomes counts. While in some other species new cytotypes have been added to the already existing diploid (Thalictrum foetidum L., new, $2 n=6 \mathrm{x}=42$ (Figure 5(c)), previous, $2 n=2 \mathrm{x}=14$; Geranium pratense L., new $2 n=4 \mathrm{x}=$ 56 (Figure $5(\mathrm{~d})$ ), previous $2 n=2 \mathrm{x}=28$ ) or polyploid cytotypes (Malva verticillata L., new, $2 n=104$, previous, $2 n=$ $76,84,126)$. New/additional intraspecific cytotypes for India have also been established in Indigofera gerardiana Wall. ex Baker $(n=24,6 \mathrm{x})$, Epilobium angustifolium L. $(n=18$, $4 \mathrm{x})$, Cerastium cerastoides (L.) Britt. $(n=18,2 \mathrm{x})$, Geranium wallichianum D. Don ex Sweet $(n=14,2 x$, Figure 5(e)), and Impatiens sulcata Wall. (Don) $(n=9,2 \mathrm{x}$, Figure 5(f)). Present study also recorded additional intraspecific diploid/polyploid cytotypes from India in Ranunculus hirtellus Royle $(n=8$, $2 \mathrm{x} ; n=16,4 \mathrm{x})$ and Potentilla atrosanguinea Lodd.var. argyrophylla (Wall. ex Lehm.) Griers. and Long ( $n=21,6 x ; n=42$, 12x). As many as eight species, namely, Angelica glauca Edgew. $(n=11)$, Astragalus bicuspis Fischer $(n=8)$, Biebersteinia odora Steph. ex Fish. $(n=5$, Figure 5(g)), Bergenia stracheyi Engl. $(n=17)$, Chaerophyllum aromaticum L. $(n=11)$, Datisca cannabina L. $(n=11)$, Rosa webbiana Wall. ex Royle $(n=7)$, and Trigonella emodi Benth. $(n=8)$ have been counted chromosomally for the first time from India.

\subsection{Abnormal Cytological Events during Male Meiosis and} Pollen Fertility. Besides new chromosome reports and additional cytotypes, in some of the species meiosis was abnormal and was characterized by the presence of multivalents and/or univalents, impaired synapsis, cytomixis, and its associated meiotic aberrations such as laggards and bridges, chromatin stickiness, pycnotic chromatin, irregular distribution of chromosomes, and micronuclei at telophases/sporads consequently leading to abnormal microsporogenesis and variable amount of pollen sterility (Figures $5(\mathrm{~h})-5(\mathrm{p})$ ).

Among the abnormal taxa, 12x cytotype of $P$. atrosanguinea Lodd.var. argyrophylla (Wall. ex Lehm.) Griers. and Long is an imbalanced polyploid. Owing to the presence of high chromosome number $(2 n=84)$, it depicted a 


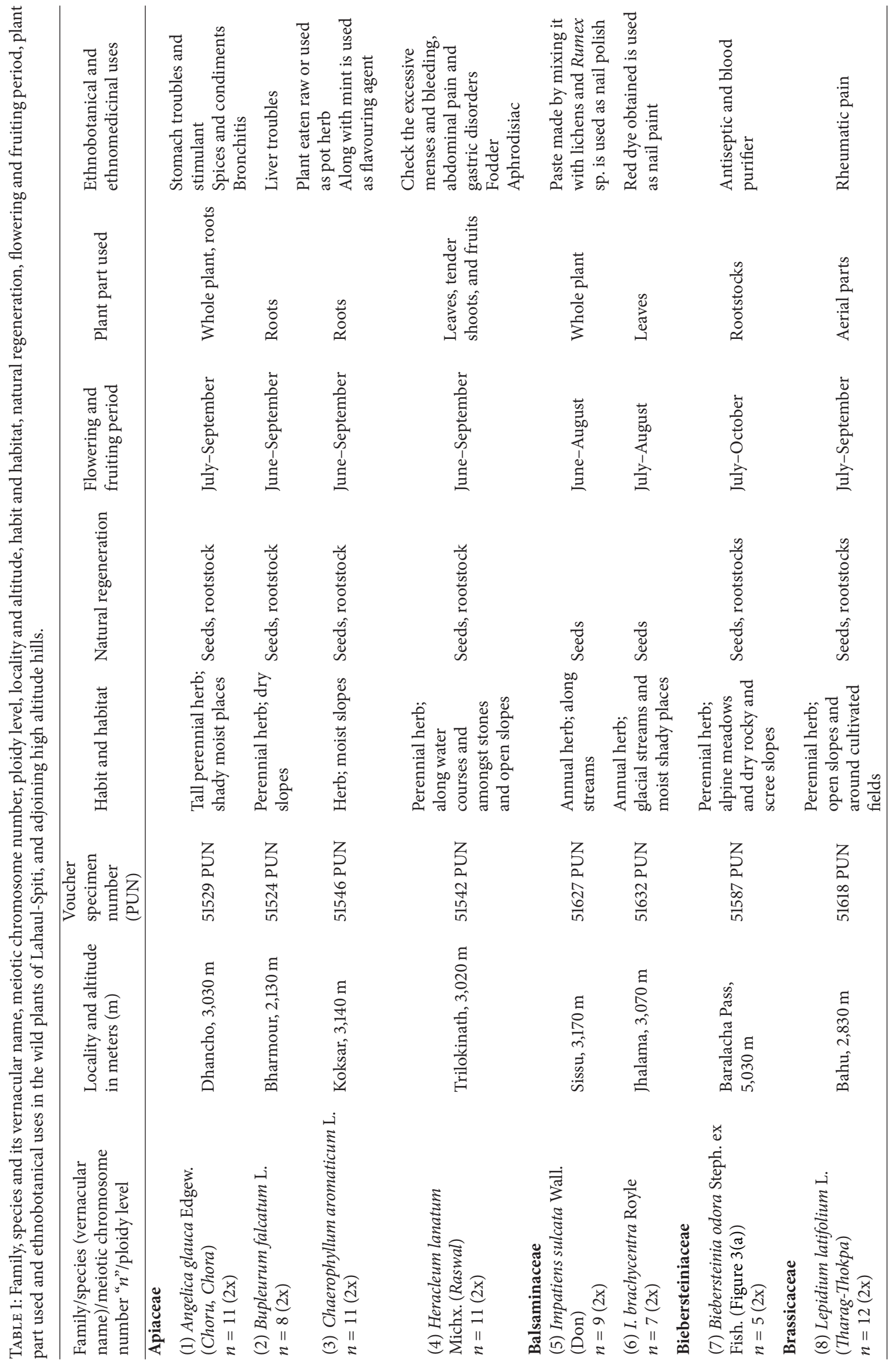




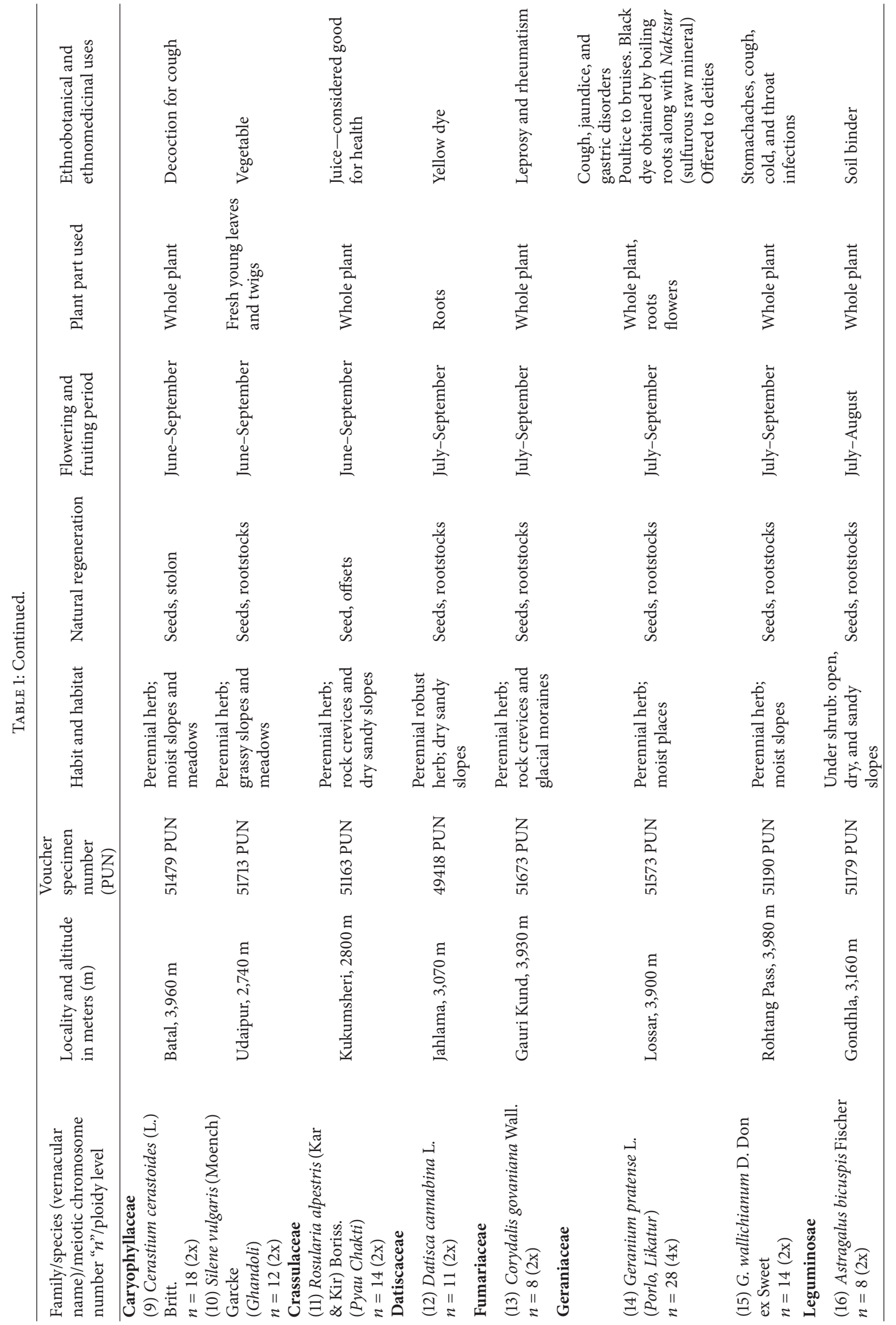




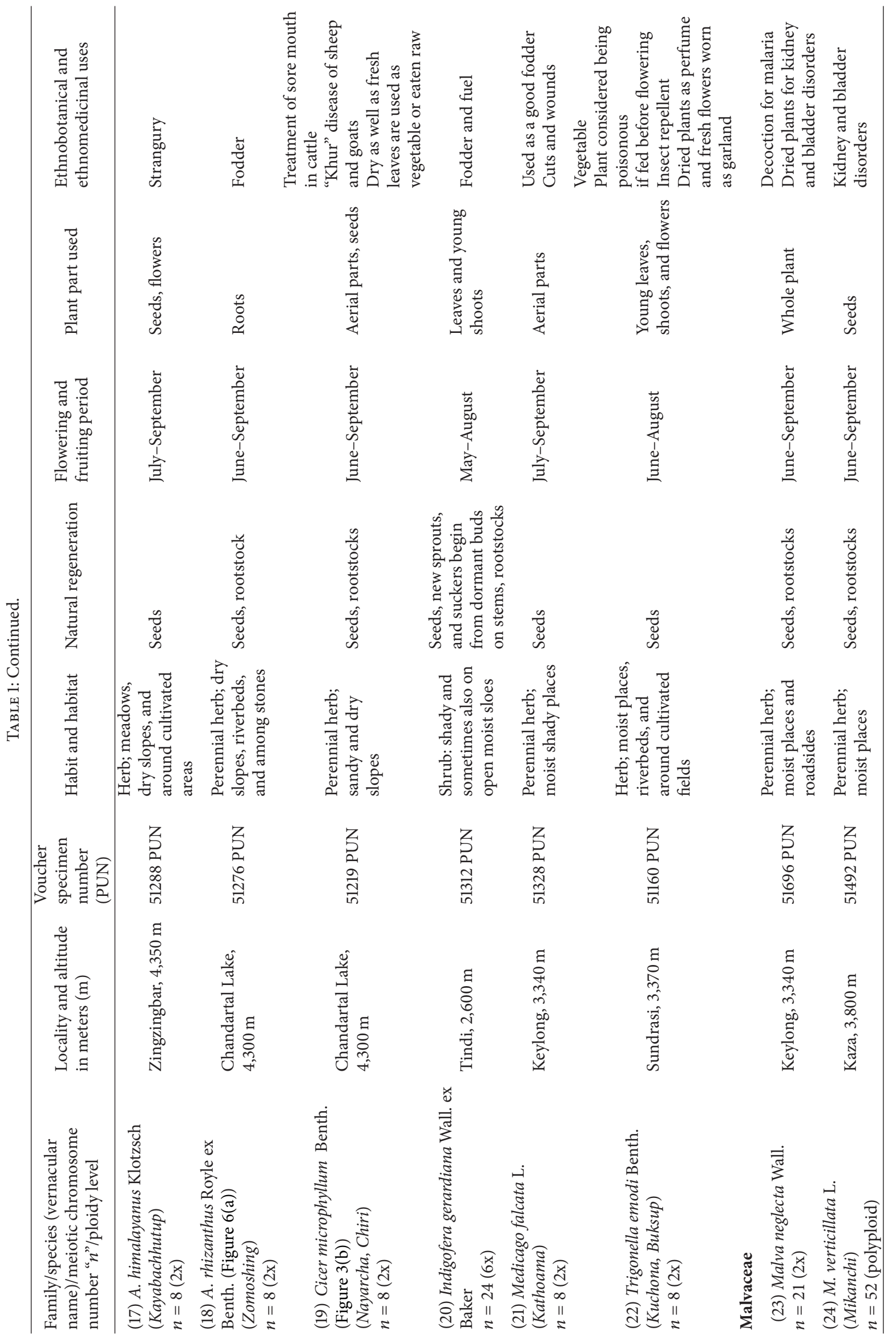




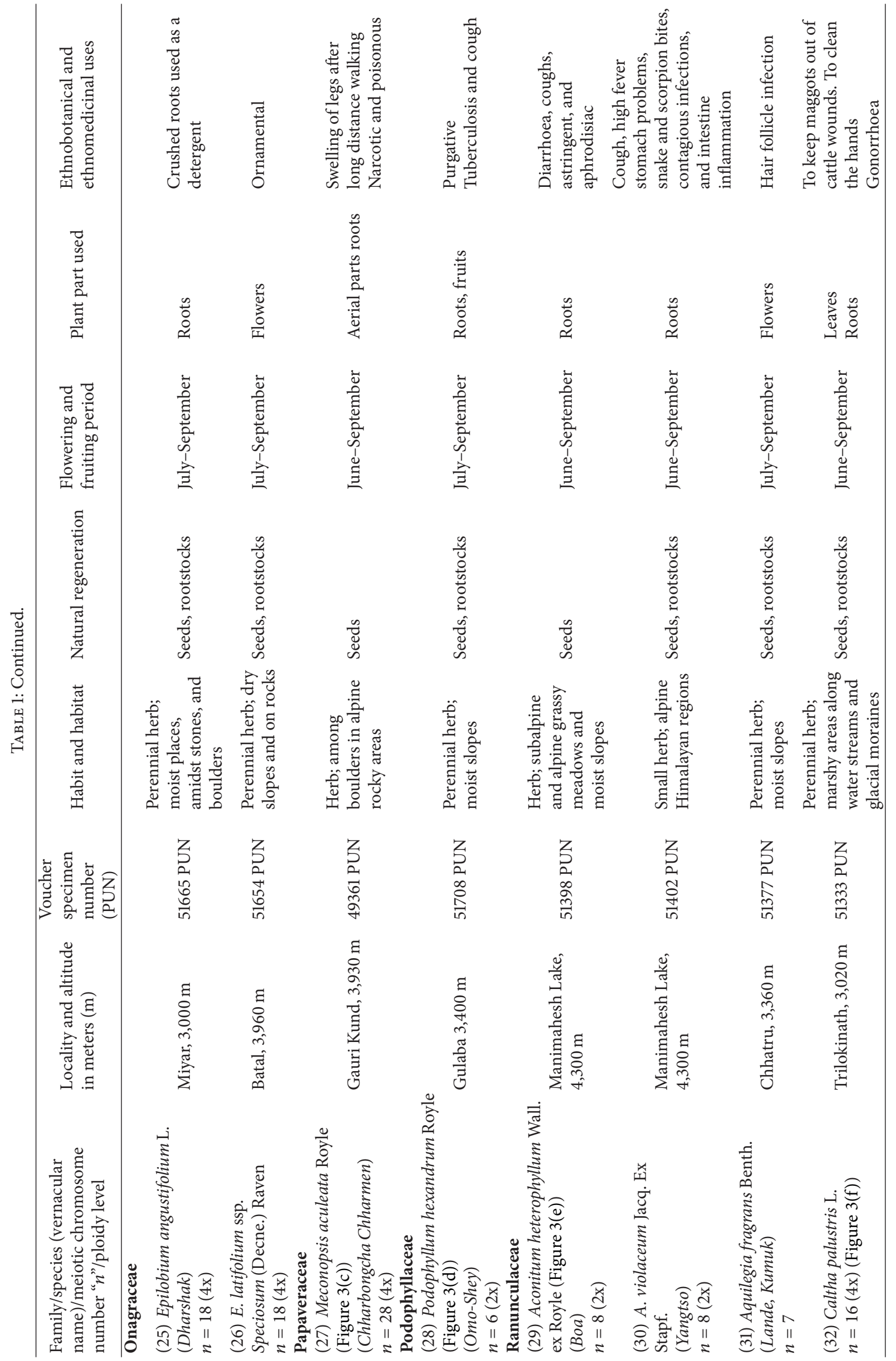




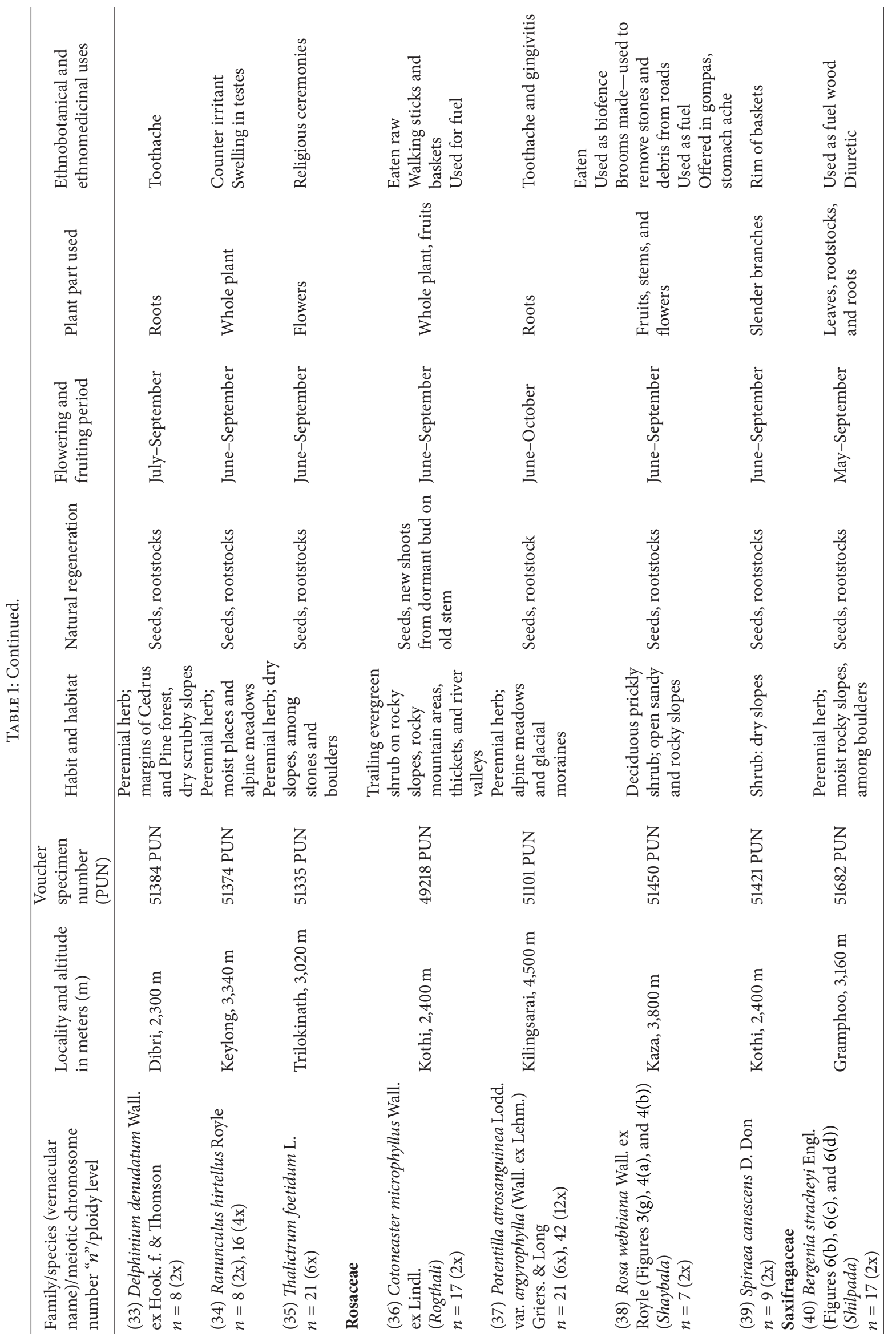




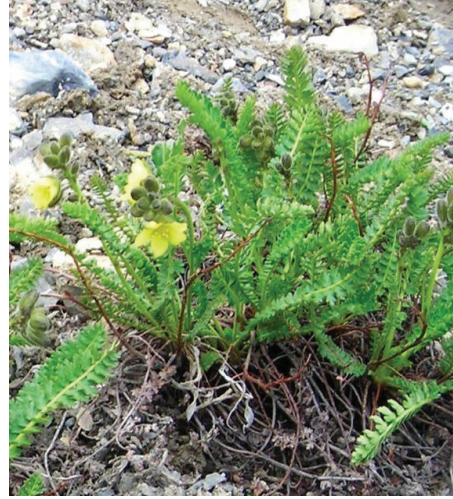

(a)

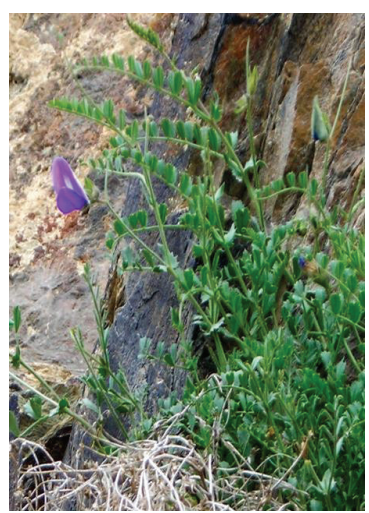

(b)

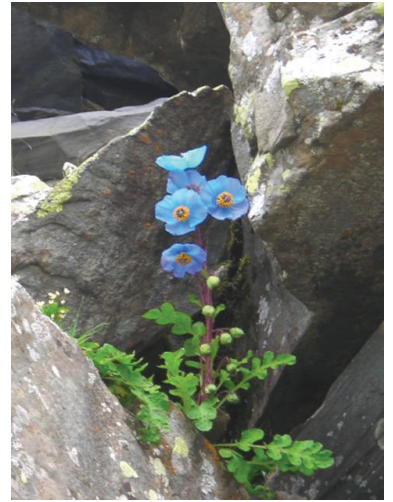

(c)

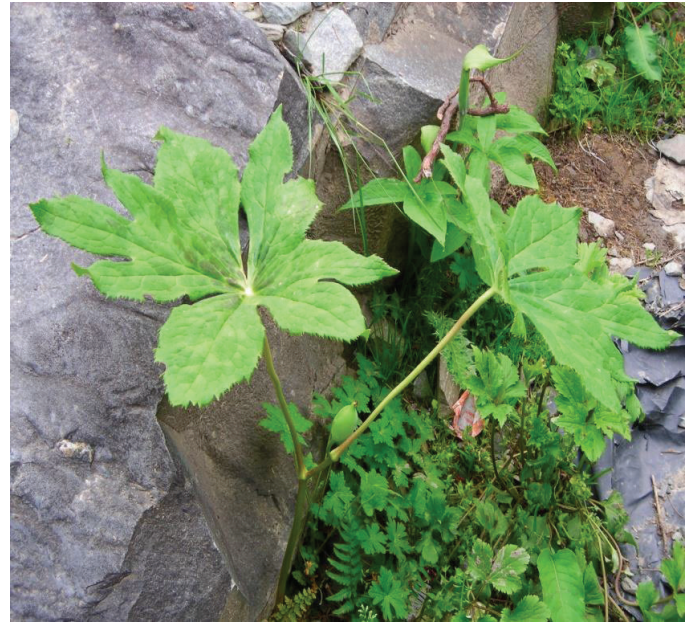

(d)

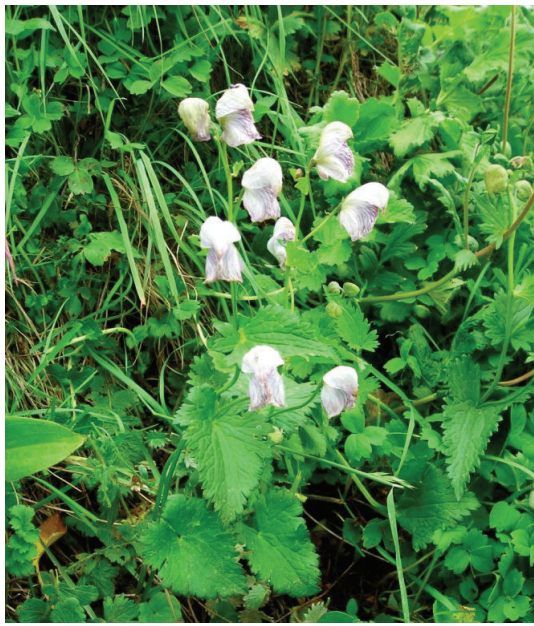

(e)

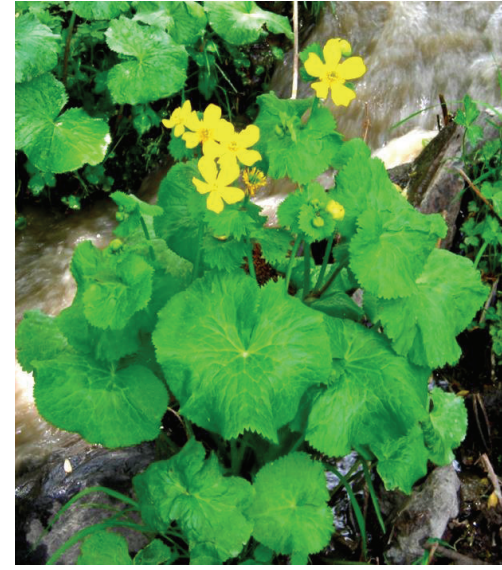

(f)

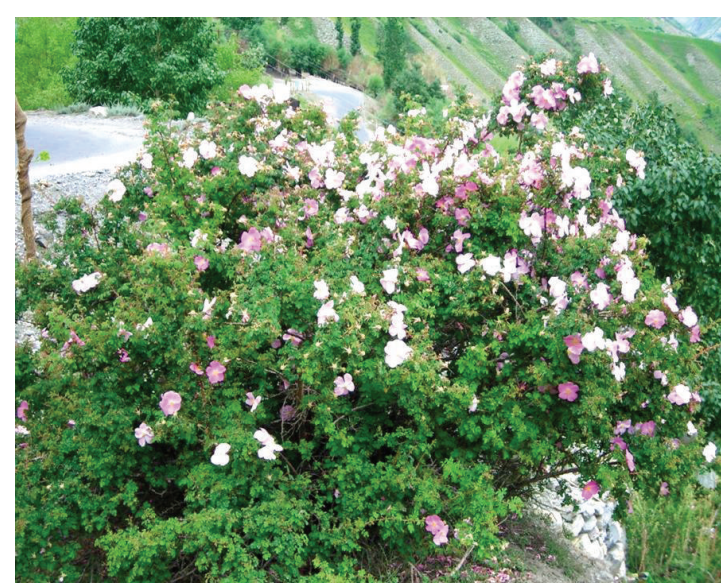

(g)

FIGURE 3: (a) Biebersteinia odora plants in a group, coming out of withered remains of stems. (b) Cicer microphyllum growing on rock. (c) An individual of Meconopsis aculeata growing among the boulders. (d) Podophyllum hexandrum. (e) Aconitum heterophyllum with greenish blue flowers having purple veins growing on moist slopes. (f) Caltha palustris with bright yellow flowers and large reniform leaves growing near water. (g) A shrub of Rosa webbiana with pink flowers.

typically irregular meiotic behaviour (presence of multivalents and/or univalents, laggards, and irregular distribution of chromosomes), abnormal microsporogenesis, and pollen sterility (14-46\%) which is the characteristic feature in such kind of imbalanced polyploids. Cytomixis which involves the interpollen mother cell transfer of chromatin material through narrow and broad cytomictic channels is existent in Astragalus bicuspis Fischer $(n=8)$, A. himalayanus Klotzsch $(n=8)$, A. rhizanthus Royle ex Benth. $(n=8)$, Caltha palustris L. $(n=16)$, Geranium pratense L. $(n=28)$, 


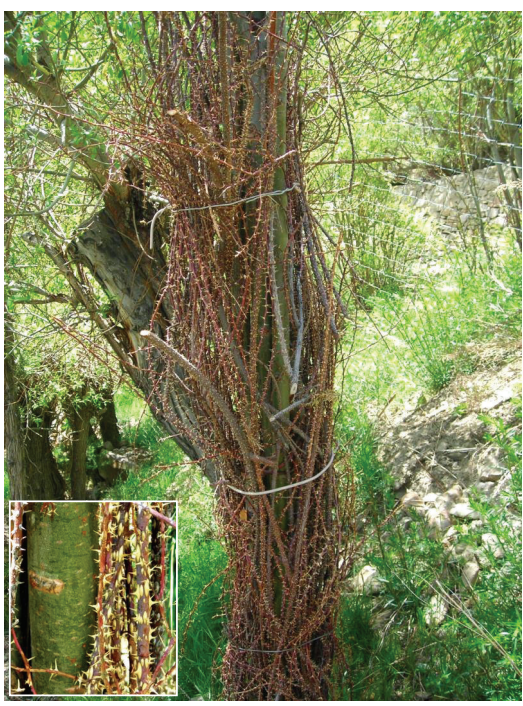

(a)

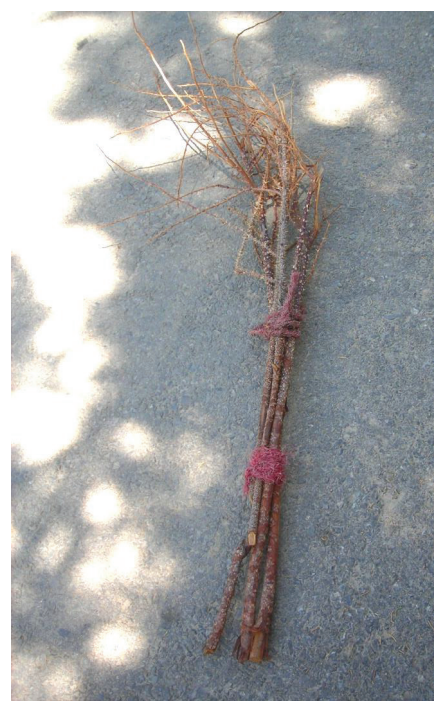

(b)

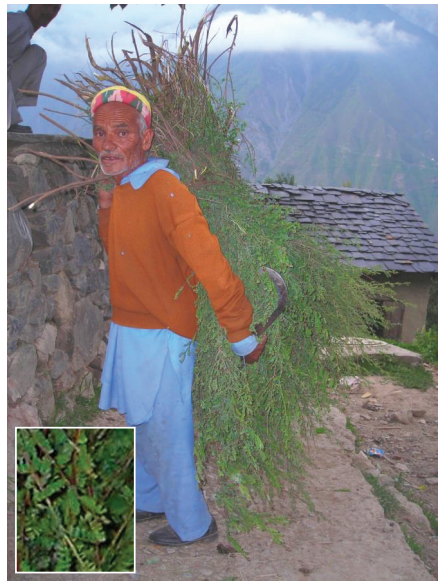

(c)

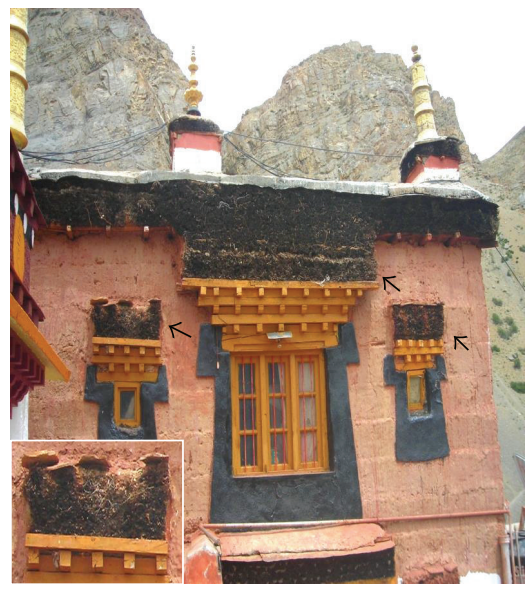

(d)

Figure 4: (a) Spiny branches of Rosa webbiana wrapped around the stem of Salix tree as a biofence. (b) A broom made of twigs of Rosa webbiana to remove stones and debris from road. (c) An old person carrying a bundle of young twigs of Indigofera gerardiana on his back to be used as a fodder and fuel. (d) Timber of some species used in house construction (arrowed).

Meconopsis aculeata Royle $(n=28)$, P. atrisanguinea Lodd. var. argyrophylla (Wall. ex Lehm.) Griers. and Long $(n=21$, 42), Trigonella emodi Benth. $(n=8)$, Rosularia alpestris (Kar and Kir) Boriss. ( $n=14)$, Silene vulgaris (Moench) Garcke $(n=12)$, Thalictrum foetidum L. $(n=21)$, and Ranunculus hirtellus Royle $(n=8,16)$. Impaired synapsis owing to the lack of pairing of homologous chromosomes in Rosularia alpestris (Kar and Kir) Boriss. resulted in the presence of all chromosomes as univalents during early prophase stages of meiosis-I and consequently abnormal microsporogenesis and pollen sterility (28\%). Besides, in Bergenia stracheyi Engl. high pollen sterility (22\%) was recorded without the occurrence of any meiotic irregularity which might be attributed to irregularities in postmeiotic events during pollen development.

3.4. Natural Propagation. Natural propagation observations made on all the 40 species revealed that majority of the species are perennial and propagate through asexual (vegetative propagation) means such as rootstocks, offsets, root suckers, and stolons (Figures 6(a)-6(d)).

\section{Discussion}

A steady stream of papers over the years have recognized the fact that the reproductive stage in the life cycle of plants is highly sensitive to different abiotic stresses [5-8] especially the low temperature conditions [9-16]. It has been observed that when plants of this area are about to enter the flowering stage, the temperature is very low (sub-zero to $15^{\circ} \mathrm{C}$ ) which seems to disrupt the meiotic process by causing various meiotic abnormalities and consequently reduced viability of gametes. Ultimately these events hinder natural propagation of plants through sexual means.

Natural propagation observations revealed that majority of the species are perennial and propagate through asexual 


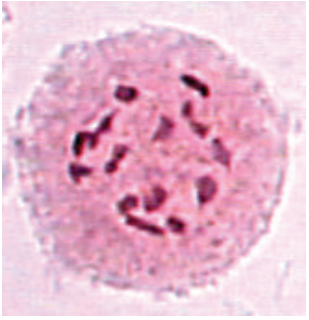

(a)

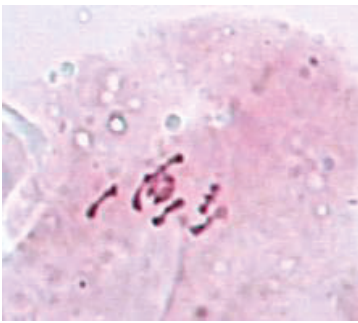

(b)

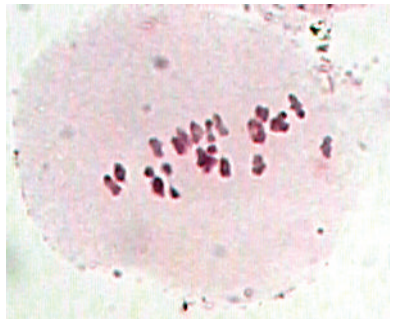

(c)

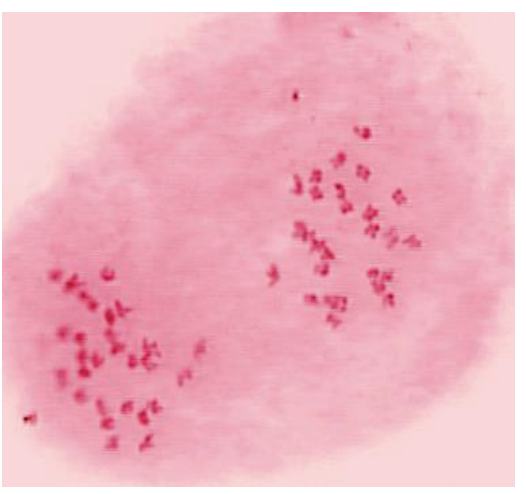

(d)

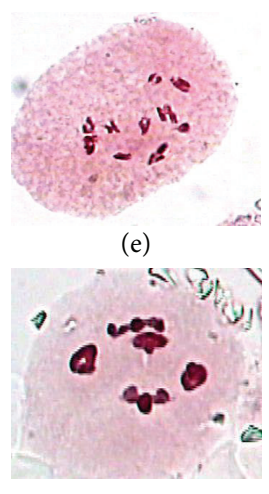

(g)

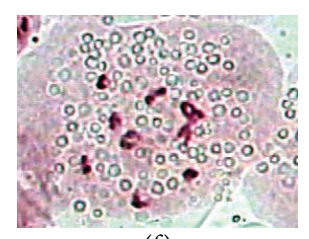

(f)

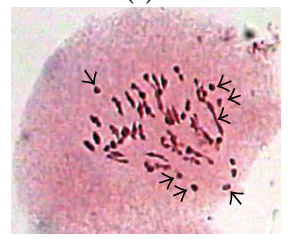

(h)

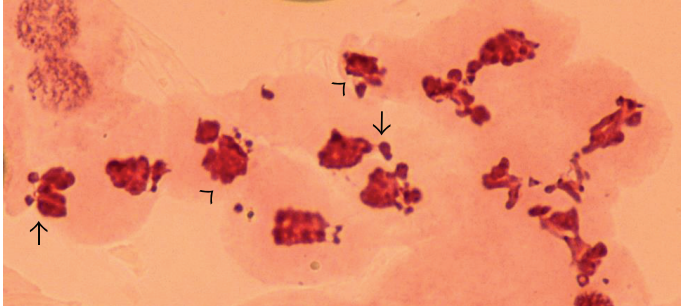

(i)

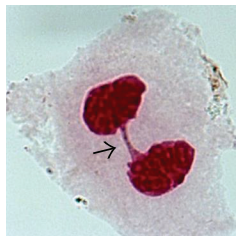

(k)

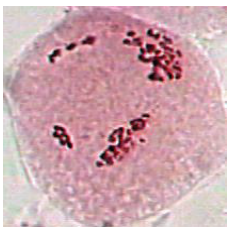

(m)

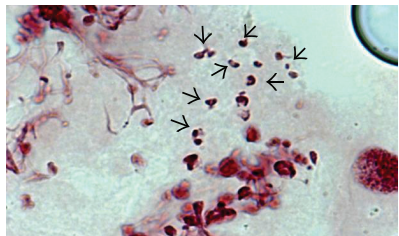

(1)

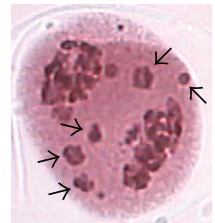

(n)

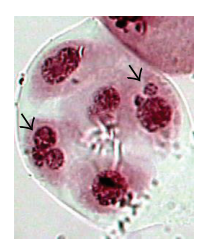

(o)

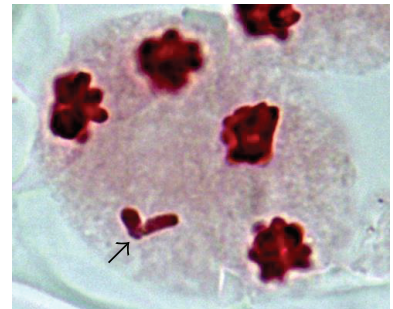

(j)

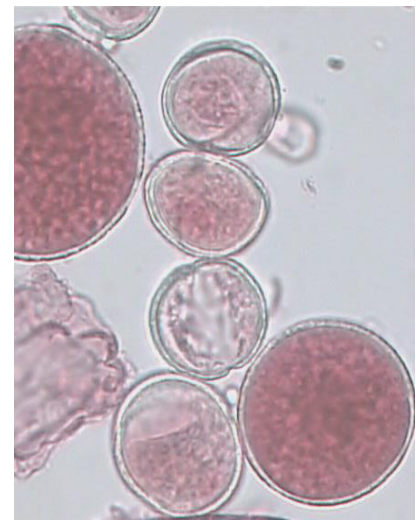

(p)

FIgURE 5: Meiotic chromosome number. (a) Rosularia alpestris, $n=14$ at metaphase-I. (b) Corydalis govaniana, $n=8$ at metaphase-I. (c) Thalictrum foetidum, $n=21$ at metaphase-I. (d) Geranium pratense, 28:28 chromosomes distributions at metaphase-II. (e) Geranium wallichianum, $n=14$ at diakinesis. (f) Impatiens sulcata, $n=9$ at metaphase-I. (g) Biebersteinia odora, $n=5$ at metaphase-I. Meiotic abnormalities in pollen mother cells (PMCs) and sterile pollen grains. (h) A PMC showing univalents (arrowed) and multivalents (arrowhead). (i) PMCs in a group showing inter-PMC chromatin transfer (arrowed) and chromatin stickiness (arrowhead). (j) A PMC showing laggards at anaphase-II. (k) A PMC showing a chromatin bridge at anaphase-II. (l) Pycnotic chromatin material scattered in the cytoplasm of PMCs. (m) A PMC showing unequal distribution of chromatin material at poles. (n) Micronuclei at telophase-I. (o) Micronuclei at sporad stage. (p) Apparently sterile (arrowed) and fertile pollen grains (arrowhead). 


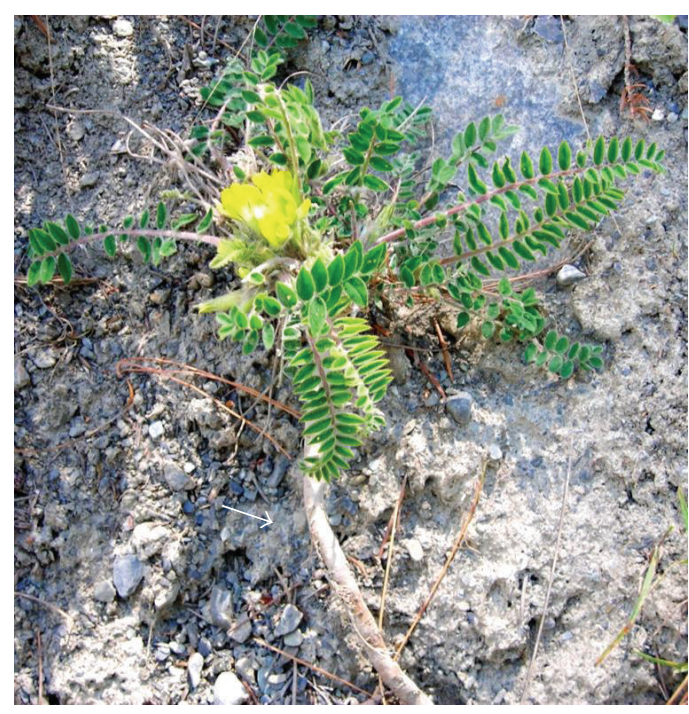

(a)

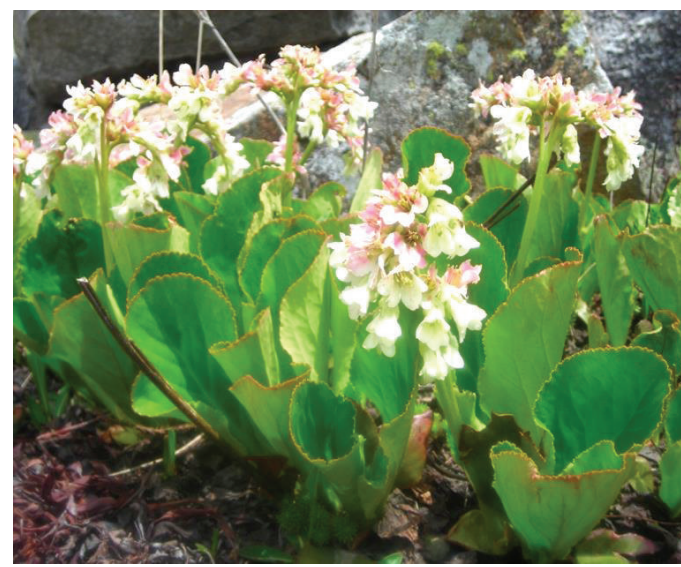

(c)

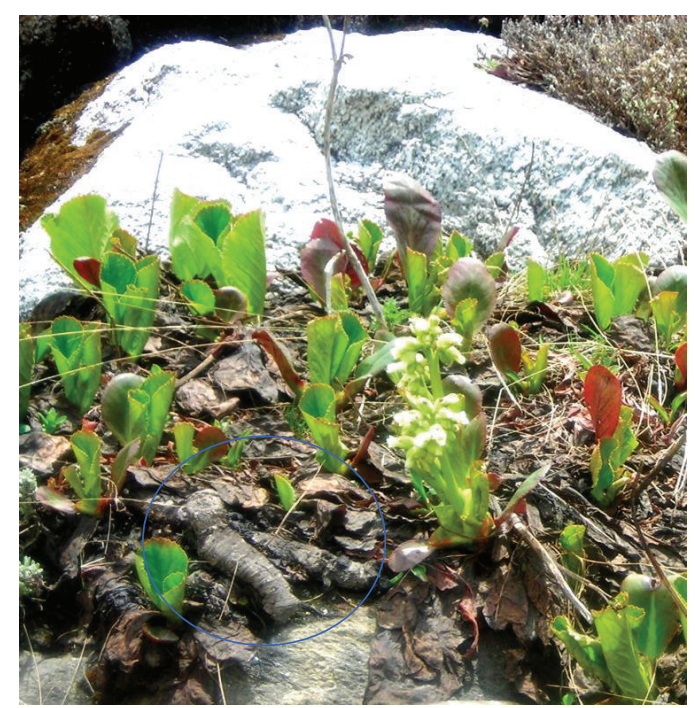

(b)

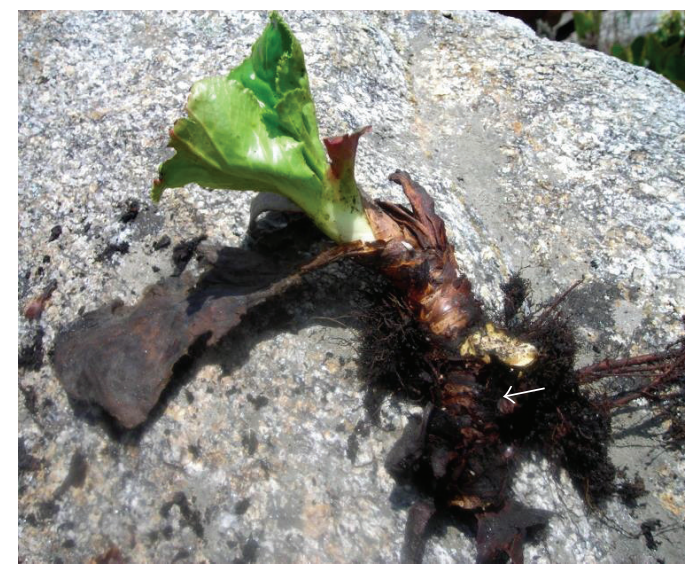

(d)

Figure 6: Natural propagation. (a) A plant grown from old rootstock (arrowed) in Astragalus rhizanthus. (b) New plants of Bergenia stracheyi coming out of the rootstocks (encircled) underlying withered leaves. (c) B. stracheyi plants in full bloom with white pinkish flowers. (d) A new sprout can be seen growing on the old rootstock (arrowed) of B. stracheyi.

means such as rootstocks, offsets, root suckers, and stolons. Thus, it is assumed that in order to survive the harsh environmental conditions and gametic sterility caused by irregular meiotic events, the plants of the area have adopted alternate mechanism of reproduction through vegetative means. Vegetative means of propagation are important for species like Meconopsis aculeata Royle, Potentilla atrosanguinea Lodd. var. argyrophylla (Wall. ex Lehm.) Griers. and Long, Bergenia stracheyi Engl., Rosularia alpestris (Kar and Kir) Boriss., and so forth, where high pollen grain sterility have been observed. Occurrence of sterility on female side in the species may pose serious problem for species existence, especially, which are rare and engendered and are overexploited for medicinal purposes. Problem becomes more serious in species like Bergenia stracheyi, Engl. and Rosularia alpestris (Kar and Kir) Boriss. which propagate through vegetative means, and perennating parts are directly collected from the wild sources. Till now these species have not been included in any of the local cultivation programme.
To date numerous valuable herbal drugs have been discovered by following the knowledge of ancient folk healers [17]. The medicinal plants used to cure various diseases by the traditional healers are gradually becoming extinct. The two factors which have been identified as major threats to the floristic diversity are the overexploitation and habitat [1821]. Majority of the plants (Aconitum heterophyllum Wall. ex Royle, Angelica glauca Edgew., Biebersteinia odora Steph. ex Fish., Bergenia stracheyi Engl., Delphinium denudatum Wall. ex Hook. f. and Thomson, Indigofera gerardiana Wall. ex Baker, Meconopsis aculeata Royle, Podophyllum hexandrum Royle, and Spiraea canescens D. Don) which have been studied presently are restricted to specific pockets with very low population density and belong to rare, critically endangered, endangered, vulnerable, threatened, and newly threatened category because of the fragile ecological conditions of this Himalayan region [20-22]. Some of the other factors which can also lead to the extinction of the local valuable herbs include agricultural expansion, heavy grazing, road 
building, increasing entry of tourists, and transport vehicles. So to study and examine different aspects of survival of the plants of the area in their natural habitats will be of colossal significance. Thus it becomes very urgent to collect information about the plants growing in such ecologically fragile region before it gets too late to respond. Immediate steps must be taken up on priority basis to preserve the ethnic knowledge and the plants of the region. The gradual exposure of younger generations to western civilization and limited employment opportunities are two important threats that may lead to serious losses of traditional knowledge, and it will not be surprising that after a decade or so nobody will be able to tell about the plants that were once used traditionally for ethnobotanical and medicinal purposes. In view of the above points it is suggested that an institute dealing with the conservation of plants and their traditional uses must be set up in the region. The benefits arising from ethnic knowledge must be shared among the local people and employment must be provided to local youth. Present investigations also form the basis for exploitation of intraspecific chromosomal variation/new cytotypes recorded in some of the presently studied species to detect biochemical diversity in these medicinally important plants.

\section{Acknowledgments}

The authors are thankful to the local people and medicine men for their help and cooperation during field study. The authors wish to thank the University Grants Commission, New Delhi, India, for providing financial assistance under DRS SAP I and II, ASIST programme, and Dr. D. S. Kothari Post-Doctoral Fellowship Award Letter no. F.4-2/2006(BSR)/ 13-427/2011(BSR) to Puneet Kumar. Thanks are also due to the Head of Department of Botany, Punjabi University, Patiala, India, for necessary laboratory and internet facilities. The authors declare that there is no conflict of interests regarding the publication of this paper.

\section{References}

[1] I. Hedberg, "Research on medicinal and poisonous plants of tropics," in Past, Present and Future in MedicInal and Poisonous Plants of the Tropics, A. J. M. Leewenerg, Ed., pp. 9-15, International Book Distributors, Dehra Dun, India, 1987.

[2] B. S. Aswal and B. N. Mehrotra, Flora of Lahaul-Spiti (A Cold Desert in North West Himalaya), Bishen Singh Mahendra Pal Singh, Dehra Dun, India, 1994.

[3] D. S. Dhaliwal and M. Sharma, Flora of Kullu District (Himachal Pradesh), Bishen Singh Mahendra Pal Singh, Dehra Dun, India, 1999.

[4] H. Singh and M. Sharma, Flora of Chamba District (Himachal Pradesh), Bishen Singh Mahendra Pal Singh, Dehra Dun, India, 2006.

[5] J. T. Baker, L. H. Allen, and K. J. Boote, "Temperature effects on rice at elevated $\mathrm{CO}_{2}$ concentration," Journal of Experimental Botany, vol. 43, no. 7, pp. 959-964, 1992.

[6] V. A. Fuzinatto, M. S. Pagliarini, and C. B. Valle, "Evaluation of microsporogenesis in an interspecific Brachiaria hybrid
(Poaceae) collected in distinct years," Genetics and Molecular Research, vol. 7, no. 2, pp. 424-432, 2008.

[7] M. Rezaei, A. Arzani, and B. E. Sayed-Tabatabaei, "Meiotic behaviour of tetraploid wheats (Triticum turgidum L.) and their synthetic hexaploid wheat derivates influenced by meiotic restitution and heat stress," Journal of Genetics, vol. 89, no. 4, pp. 401-407, 2010.

[8] S. Sato, M. Kamiyama, T. Iwata, N. Makita, H. Furukawa, and H. Ikeda, "Moderate increase of mean daily temperature adversely affects fruit set of Lycopersicon esculentum by disrupting specific physiological processes in male reproductive development," Annals of Botany, vol. 97, no. 5, pp. 731-738, 2006.

[9] F. Bretagnolle and J. D. Thompson, "Tansley Review No. 78. Gametes with the somatic chromosome number: mechanisms of their formation and role in the evolution of autopolyploid plants," New Phytologist, vol. 129, no. 1, pp. 1-22, 1995.

[10] A. Hedhly, "Sensitivity of flowering plant gametophytes to temperature fluctuations," Environmental and Experimental Botany, vol. 74, no. 1, pp. 9-16, 2011.

[11] P. Kumar and V. K. Singhal, "Chromosome number, male meiosis and pollen fertility in selected angiosperms of the cold deserts of Lahaul-Spiti and adjoining areas (Himachal Pradesh, India)," Plant Systematics and Evolution, vol. 297, no. 3-4, pp. 271-297, 2011.

[12] A. S. Mason, M. N. Nelson, G. Yan, and W. A. Cowling, "Production of viable male unreduced gametes in Brassica interspecific hybrids is genotype specific and stimulated by cold temperatures," BMC Plant Biology, vol. 11, article 103, 2011.

[13] J. Ramsey and D. W. Schemske, "Pathways, mechanisms, and rates of polyploid formation in flowering plants," Annual Review of Ecology and Systematics, vol. 29, pp. 467-501, 1998.

[14] V. K. Singhal and P. Kumar, "Variable sized pollen grains due to impaired male meiosis in the cold desert plants of Northwest Himalayas (India)," in Pollen: Structure, Types and Effects, B. J. Kaiser, Ed., pp. 101-126, Nova Science, New York, NY, USA, 2010.

[15] V. K. Singhal, P. K. Rana, and P. Kumar, "Syncytes during male meiosis resulting in $2 \mathrm{n}$ pollen grain formation in Lindelofia longiflora var. falconeri," Journal of Systematics and Evolution, vol. 49, no. 5, pp. 406-410, 2011.

[16] M. te Beest, J. J. Le Roux, D. M. Richardson et al., "The more the better? The role of polyploidy in facilitating plant invasions," Annals of Botany, vol. 109, pp. 19-45, 2012.

[17] N. Ekka and V. K. Dixit, "Ethno-pharmacognostical studies of medicinal plants of Jashpur district, Chattisgarh," International Journal of Green Pharmacy, vol. 1, pp. 2-4, 2007.

[18] C. P. Kala, "Status and conservation of rare and endangered medicinal plants in the Indian trans-Himalaya," Biological Conservation, vol. 93, pp. 371-379, 1999.

[19] C. P. Kala and N. Manjrekar, "Ethno-medicobotany of Indian trans-Himalaya: a case study from Spiti," Journal Economic and Taxonomic Botany, vol. 23, pp. 177-183, 1999.

[20] M. S. Rana and S. S. Samant, "Threat categorisation and conservation prioritisation of floristic diversity in the Indian Himalayan region: a state of art approach from Manali Wildlife Sanctuary," Journal for Nature Conservation, vol. 18, no. 3, pp. 159-168, 2010.

[21] S. S. Samant, U. Dhar, and R. S. Rawal, "Biodiversity status of a protected area in West Himalaya: askot wildlife sanctuary," International Journal of Sustainable Development and World Ecology, vol. 5, no. 3, pp. 194-203, 1998. 
[22] T. K. Ved and V. Tandon, CAMP Report: Conservation Assessment and Management Plan, Workshop held at Kullu district in Himachal Pradesh, FRLHT, Bangalore, India, 1998. 

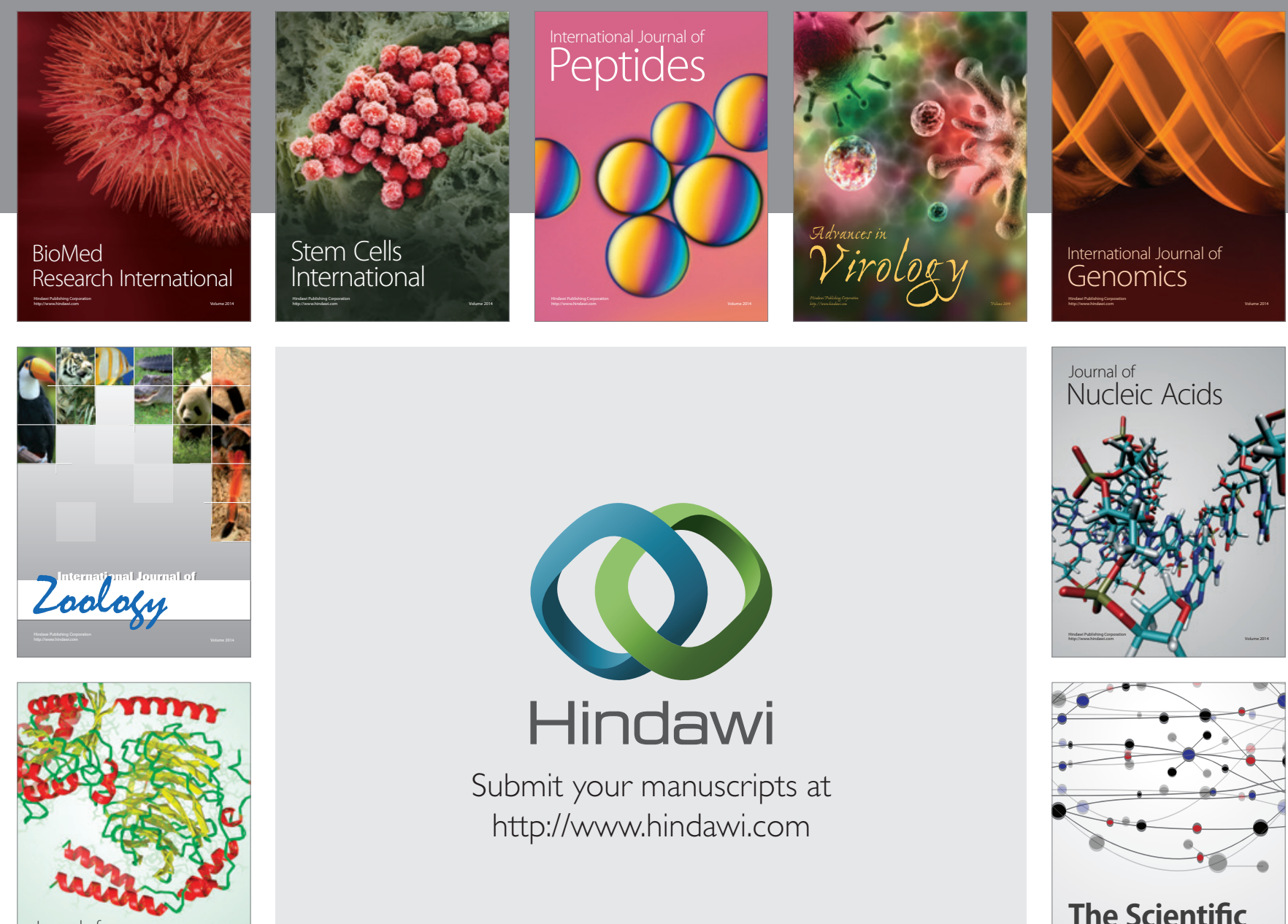

Submit your manuscripts at

http://www.hindawi.com

Journal of
Signal Transduction
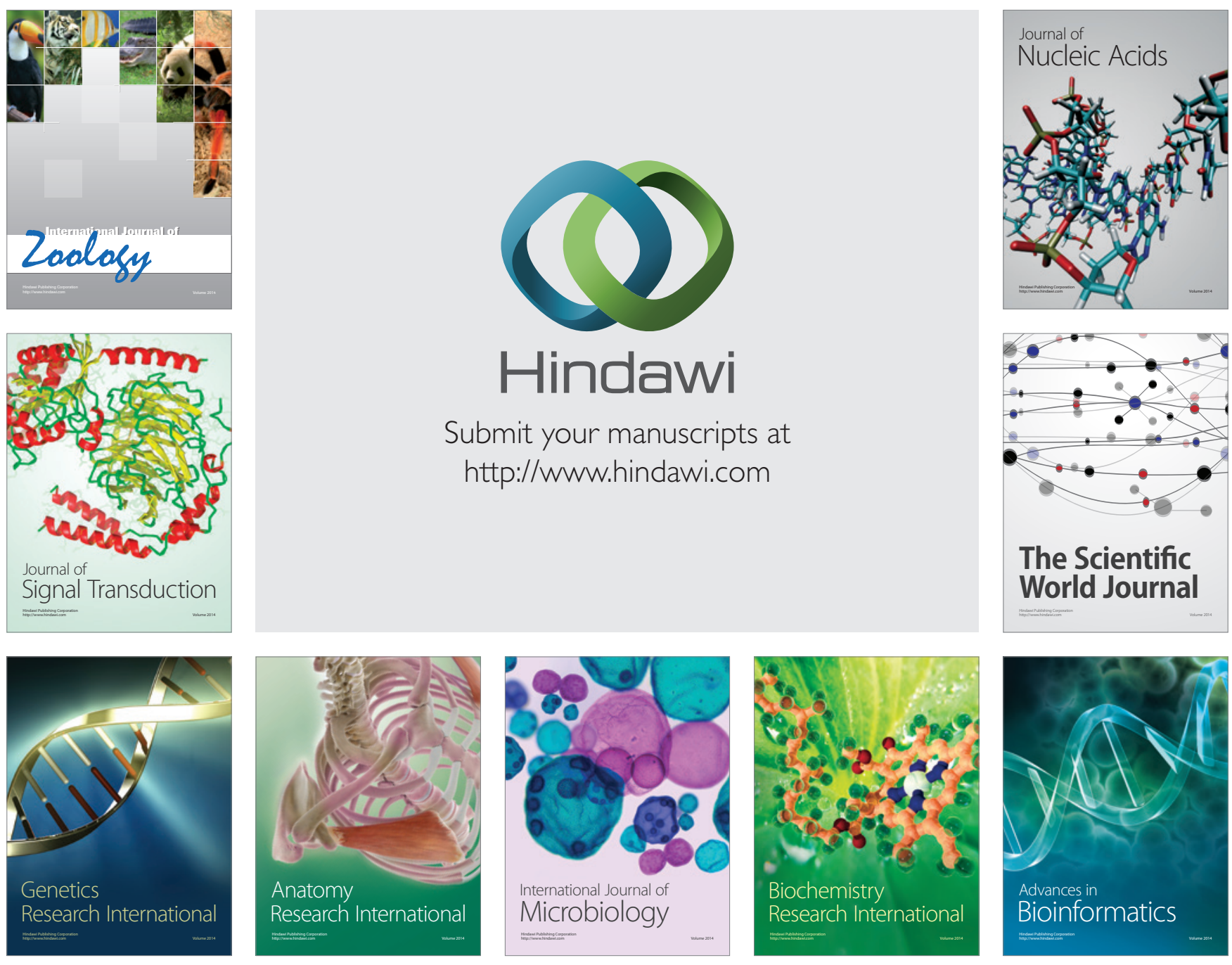

The Scientific World Journal
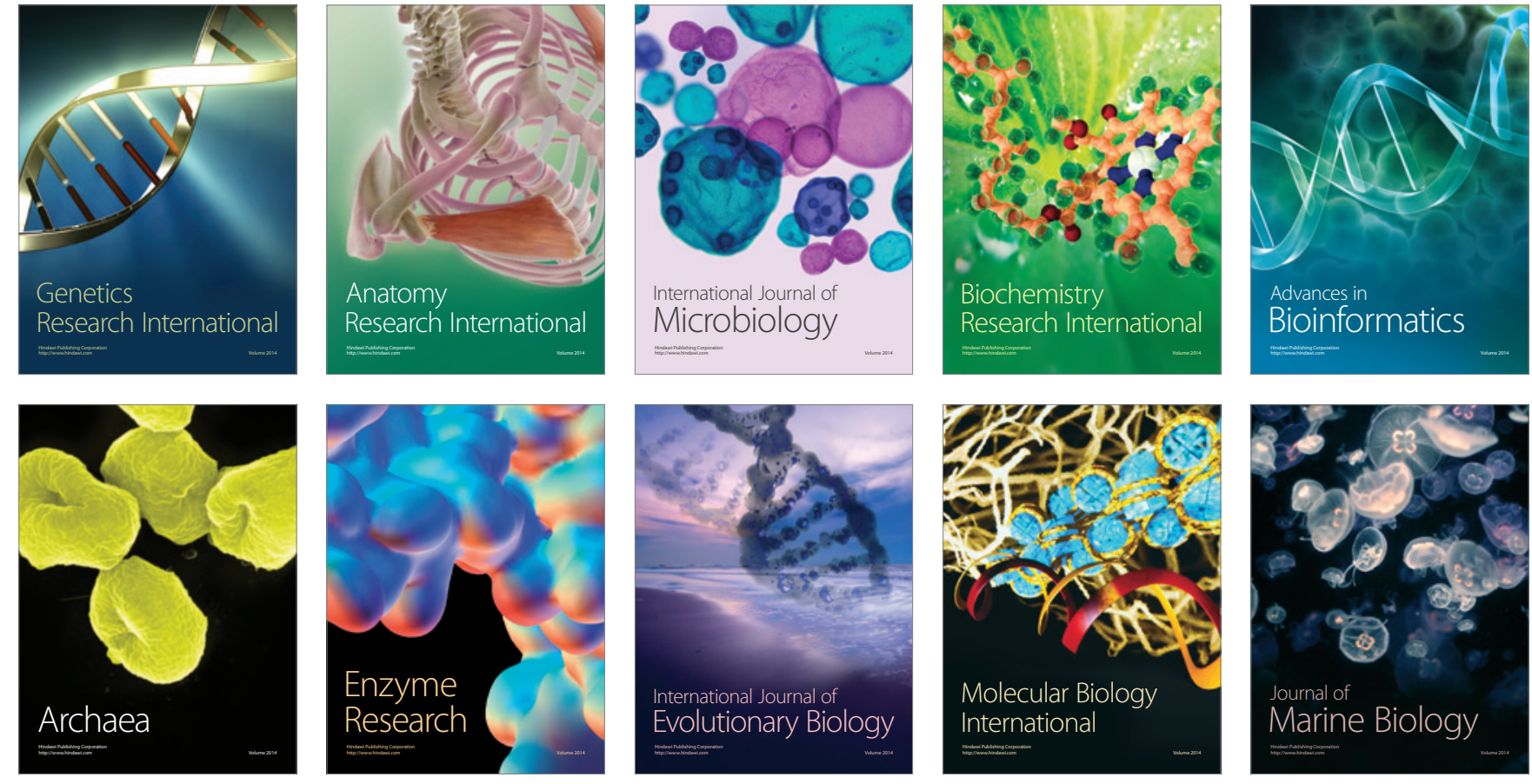